\title{
PERAN KOMITMEN ORGANISASIONAL DALAM MEMEDIASI PENGARUH KEPEMIMPINAN TRANSFORMASIONAL TERHADAP TURNOVER INTENTION KARYAWAN AMBIENTE SPA
}

\author{
Komang Sri Astuti Dewi ${ }^{1}$ \\ I Gusti Ayu Manuati Dewi ${ }^{2}$ \\ ${ }^{1,2}$ Fakultas Ekonomi dan Bisnis Universitas Udayana (Unud), Bali, Indonesia \\ email: astuti171298@gmail.com
}

\begin{abstract}
ABSTRAK
Turnover intention merupakan salah satu bentuk pergerakan karyawan keluar dari organisasi yang dapat berujung pada keputusan karyawan meninggalkan pekerjaannya. Tujuan penelitian adalah menguji pengaruh kepemimpinan transformasional terhadap turnover intention dimediasi oleh komitmen organisasional. Penelitian dilakukan di Ambiente Spa dengan 100 orang sampel, menggunakan metode sampel jenuh dan pengumpulan data dilakukan melalui wawancara serta penyebaran kuesioner. Teknik analisis data yang digunakan adalah Uji Asumsi Klasik dan Analisis Jalur. Hasil dari penelitian menunjukkan bahwa kepemimpinan transformasional memiliki pengaruh positif dan signifikan terhadap komitmen organisasional, kepemimpinan transformasional dan komitmen organisasional berpengaruh negatif dan signifikan terhadap turnover intention serta komitmen organisasional memiliki peran sebagai veriabel mediasi secara negatif dan signifikan pengaruh kepemimpinan transformasional terhadap turnover intention. Kepemimpinan transformasional dan komitmen organisasional secara nyata dapat menurunkan turnover intention, ketika kepemimpinan transformasional yang dirasakan oleh karyawan meningkatkan komitmen organisasi, maka komitmen organisasi yang dirasakan oleh karyawan menjadi semakin kuat sehingga berpotensi menurunkan turnover intention.

Kata kunci : Kepemimpinan Transformasional, Komitmen Organisasional, Turnover Intention
\end{abstract}

\begin{abstract}
Turnover intention is form of movement of employees which can lead to employee leaving. The purpose of study was to examine the effect of transformational leadership on turnover intention mediated by organizational commitment. The study was conducted at Ambiente Spa with 100 samples, using the saturated sample method and data collected through interviews and questionnaires. Classic Assumption Test and Path Analysis were used. Transformational leadership has positive and significant influence on organizational commitment, transformational leadership and organizational commitment has a negative and significant effect on turnover intention and organizational commitment has a role as a veriable mediation negatively and significantly the effect of transformational leadership on turnover intention. Transformational leadership and organizational commitment can significantly reduce turnover intention, when transformational leadership perceived by employees increases organizational commitment, the organizational commitment felt by employees becomes stronger so that it has the potential to reduce turnover intention. Keywords: Transformational Leadership, Organizational Commitment, Turnover Intention
\end{abstract}




\section{PENDAHULUAN}

Sumber daya manusia (SDM) merupakan aset paling penting yang dimiliki oleh perusahaan. Keseluruhan kegiatan perusahaan bergantung pada SDM yang ada sehingga dapat dikatakan bahwa SDM menjadi penentu berhasil atau tidaknya sebuah perusahaan mencapai tujuannya. Perusahaan harus mampu mengelola SDM dengan baik guna mencapai visi dan misi perusahaan. Pemimpin organisasi serta bagian yang menangani sumber daya manusia harus memahami dengan baik masalah sumber daya manusia agar dapat mengelola SDM dengan baik. Peristiwa yang sering terjadi di dalam suatu sistem dan pengelolaan sumber daya manusia di beberapa perusahaan adalah bagaimana karyawan itu sendiri bersikap. Salah satu bentuk sikap karyawan adalah turnover intention, yaitu pergerakan karyawan keluar dari organisasi yang dapat berujung pada keputusan karyawan meninggalkan pekerjaannya (Andini et al., 2018)

Turnover merupakan problematika yang sering muncul pada sebuah perusahaan yang menyangkut keinginan keluarnya karyawan, dimana keinginan karyawan untuk keluar menggambarkan rendahnya loyalitas karyawan terhadap perusahaan (Ksama \& Wibawa, 2016). Azeez et al. (2016) menyatakan bahwa tingginya tingkat turnover akan mengurangi efisiensi dan produktivitas perusahaan, sebaliknya jika tingkat turnover rendah maka efisiensi dan produktifitas perusahaan akan terjaga. Sianipar \& Kristiana (2014) berpendapat bahwa turnover intention merupakan keinginan karyawan untuk berhenti dari perusahaan karena alasan berasal dari diri sendiri (sukarela) ataupun pemecatan dari perusahaan (tidak sukarela). Tingginya tingkat turnover perusahaan akan berdampak bagi pendapatan perusahaan karena turnover menimbulkan biaya perekrutan, biaya pelatihan, dan biaya yang dikeluarkan untuk mengisi posisi yang kosong di dalam perusahaan (Khan \& Du, 2015). Faktor - faktor yang mempengaruhi turnover intention antara lain kepemimpinan transformasional dan komitmen organisasional.

Kepemimpinan transformasional merupakan kemampuan pemimpin yang menginspirasi para pengikut untuk mengenyampingkan kepentingan pribadi mereka demi keberlangsungan organisasi dan pemimpin memiliki pengaruh besar pada setiap karyawannya. Kepemimpinan sebagai proses dimana pemimpin mempengaruhi pengikutnya untuk percaya bahwa mereka harus bekerja sama dalam mencapai tujuan bersama (Yukl, 2015:6). Pada saat manajer atau pimpinan dapat menerapkan gaya kepemimpinan transformasional, maka akan meningkatkan kesetiaan karyawan dan rasa hormat kepada pimpinan serta bawahan akan merasa termotivasi untuk melakukan pekerjaan lebih dari yang diharapkan. Ketika karyawan merasa nyaman dengan pemimpin mereka, karyawan lebih cenderung untuk tinggal di perusahaan, sebaliknya ketika pemimpin merupakan sumber ketidaknyamanan bagi karyawan maka kecenderungan untuk meninggalkan perusahaan akan meningkat (El-Badawy \& Bassiouny, 2014)

Hasil penelitian yang dilakukan oleh Rohmawati (2017) dalam penelitiannya menghasilkan adanya pengaruh negatif signifikan antara gaya kepemimpinan transformasional terhadap turnover intention, dimana seorang pemimpin bisa menjadi salah satu faktor karyawan untuk keluar apabila karyawan 
tersebut merasa tidak diperlakukan dengan baik, komunikasi yang kurang baik dan pemimpin yang tidak memberi contoh yang baik terhadap bawahannya. Gul et al. (2012) juga menyatakan ada pengaruh negatif dan signifikan gaya kepemimpinan transformasional terhadap keinginan untuk keluar karyawan. Sedangkan, hasil ini berlawanan dengan penelitian Long et al. (2012), Peachey et al. (2015), Amin et al. (2018) menyatakan bahwa meskipun gaya kepemimpinan transformasional yang ditemukan memiliki hubungan negatif dengan turnover intention tetapi korelasi dua variabel ini tidak signifikan, hal ini mengindikasikan bahwa meskipun pemimpin sudah mampu menjadi inspirasi dan mampu mendorong karyawan untuk lebih baik namun itu tidak mengurangi niat dan perasaan karyawan untuk meninggalkan organisasi.

Komitmen organisasional juga merupakan salah satu faktor yang berhubungan dengan turnover intention. Komitmen organisasional adalah kondisi dimana psikologis yang dirasakan oleh anggota organisasi dapat dilihat dari loyalitas dan fokus terhadap tujuan organisasi. Komitmen organisasional merupakan suatu ikatan dan loyalitas yang dimiliki karyawan untuk melibatkan diri secara aktif dalam organisasi demi kemajuan organisasi. Ketika kayawan mempunyai loyalitas dan rasa memiliki yang tinggi pada organisasi, maka ia akan rela untuk tetap menjadi bagian dari organisasi agar tujuan individu maupun tujuan organisasi dapat terwujud. Namun, jika loyalitas dan rasa memiliki dari karyawan sangat rendah maka tidak dapat dipungkiri karyawan tersebut akan memilih untuk mengundurkan diri (Sianipar \& Kristiana, 2014). Pengukuran untuk komitmen organisasional dilakukan dengan menggunakan tiga dimensi yang terdapat dalam komitmen organisasional yaitu komponen afektif yang merujuk pada keterikatan emosional, identifikasi dan keterlibatan karyawan pada organisasi. Komponen bersinambung merujuk pada komitmen karyawan berdasarkan pada biaya yang akan diterima karyawan ketika meninggalkan organisasi. Komponen normatif merujuk pada perasaan yang dimiliki karyawan terkait dengan kewajibannya pada organisasi.

Permatasari \& Saladin (2017) menyatakan bahwa komitmen organisasional berkaitan dengan sikap pengikut yang menunjukkan keterlibatan dan perhatian yang tinggi terhadap kesuksesan perusahaannya, pengikut yang mempunyai rasa loyal yang tinggi dalam pekerjaan dan tidak memiliki keinginan untuk keluar dari perusahaan merupakan pendorong timbulnya komitmen organisasional. Komitmen organisasional memiliki hubungan yang negatif dan signifikan dengan turnover intention, dimana semakin tinggi komitmen organisasional akan semakin menurunkan keinginan karyawan untuk keluar dari pekerjaannya (Sartika, 2014). Sejalan dengan penelitian yang dilakukan oleh Putra (2016) yang menyatakan bahwa komitmen organisasional memiliki pengaruh negatif dan signifikan terhadap turnover intention, berarti apabila karyawan memiliki loyalitas, keinginan berkorban yang tinggi untuk memberikan kontribusi yang besar bagi organisasi maka turnover intention akan menurun. Oleh karena itu, semakin tinggi komitmen organisasional, maka akan semakin rendah niat karyawan untuk berpindah.

Hasil berlawanan ditemukan pada penelitian Satwari et al. (2016) dimana komitmen afektif secara parsial berpengaruh tidak signifikan terhadap turnover 
intention di Hotel Swiss-Belinn Malang, meskipun memiliki komitmen afektif yang tinggi tetap memiliki kemungkinan untuk berpindah pekerjaan apabila ada kesempatan untuk memperoleh pekerjaan yang bisa memberikan gaji yang lebih besar. Sejalan dengan penelitian Rahmawati \& Wahyuningsih (2018) yang menyatakan bahwa tidak ada hubungan yang signifikan antara komitmen organisasi dengan intensi turnover karyawan, hal ini berarti jika komitmen organisasional meningkat tidak mempengaruhi peningkatan atau penurunan intensi turnover karyawan.

Pemimpin transformasional sangat dibutuhkan oleh setiap karyawan, dengan kepemimpinan transformasional akan membuat kecerdasan emosional yang dimiliki masing - masing anggota dapat terkontrol dengan baik sehingga dapat meningkatkan efektifitas dalam perusahaan. Hasil penelitian yang dilakukan oleh Dariush et al., (2016) menyebutkan bahwa kepemimpinan transformasional berpengaruh positif terhadap komitmen organisasional karyawan. Hasil yang sama juga didukung oleh Permatasari \& Saladin (2017) dan Suardani (2018) dimana kepemimpinan transformasional memiliki pengaruh positif dan signifikan terhadap komitmen organisasional karyawan. Semakin baik kepemimpinan transformasional maka meningkatkan komitmen karyawan terhadap organisasi. Sedangkan pada penelitian Syarief et al. (2017) yang dilakukan di FEB UI menunjukkan bahwa kepemimpinan transformasional tidak berpengaruh terhadap komitmen organisasional para karyawan. Artinya adalah gaya memimpin di FEB UI tidak mempengaruhi sikap rasa memiliki, kebutuhan dan rasa tanggung jawab untuk tetap tinggal di instansi pada karyawan.

Penelitian ini dilakukan di Ambiente Spa yang merupakan sebuan perusahaan swasta yang bergerak dibidang penyedia jasa berbasis terapi dan relaksasi, yang berdiri sejak tahun 2003. Perusahaan ini beralamat di Jalan Raya Kuta No.98 Tuban, Bali. Berdasarkan hasil wawancara yang dilakukan terhadap 8 orang karyawan Ambiente Spa, ditemukan bahwa ada beberapa hal yang menjadi penyebab karyawan memiliki keinginan untuk keluar, diantaranya hubungan dengan pekerjaan yang dilakukan, penyebab yang paling utama terdapat peluang karir yang lebih baik di perusahaan lain. Hal tersebut dapat dilihat pada Tabel 1.

Tabel 1.

Data Turnover Karyawan Ambiente Spa Tahun 2016-2018

\begin{tabular}{|c|c|c|c|c|c|}
\hline Tahun & $\begin{array}{c}\text { Jumlah } \\
\text { Karyawan } \\
\text { Awal } \\
\text { Tahun } \\
\text { (orang) }\end{array}$ & $\begin{array}{c}\text { Jumlah } \\
\text { Karyawan } \\
\text { Akhir } \\
\text { Tahun } \\
\text { (orang) } \\
\end{array}$ & Rata - rata & $\begin{array}{c}\text { Karyawan } \\
\text { Keluar } \\
\text { (orang) }\end{array}$ & $\begin{array}{c}\text { Karyawan } \\
\text { Keluar }\end{array}$ \\
\hline 2016 & 87 & 91 & 89 & 6 & 6,74 \\
\hline 2017 & 89 & 102 & 95,5 & 7 & 7,32 \\
\hline 2018 & 91 & 89 & 90 & 12 & 13,3 \\
\hline
\end{tabular}

Sumber : Data Diolah, 2019

Data turnover karyawan sebesar 6,74 persen pada tahun 2016, dan pada tahun 2017 mengalami peningkatan menjadi 7,32 persen. Selanjutnya pada tahun 2018 kembali mengalami peningkatan menjadi 13,3 persen. Tingkat turnover 
karyawan Ambiente Spa tergolong tinggi karena melebihi 10 persen dari batas yang disarankan dimana, perputaran karyawan dikatakan normal apabila berkisar antara 5-10 persen pertahun dan dikatakan tinggi apabila lebih dari 10 persen pertahun. Dari data tersebut dapat disimpulkan adanya masalah turnover yang tinggi di Ambiente Spa.

Penelitian ini menggunakan teori pembentukan tingkah laku atau Social Exchange Theory. Hubungan antara karyawan dengan organisasi atau perusahaan merupakan suatu bentuk pertukaran sosial. Teori pertukaran sosial merupakan pandangan karywan ketika mereka telah diperlakukan dengan baik oleh organisasi, mereka akan cenderung melakukan balas budi dengan berperilaku dan berpartisipasi lebih dalam orgaisasi. Pertukaran sosial dapat terjadi ketika karyawan dan organisasi dapat memberikan suatu hal yang didasari pada kepercayaan. Karyawan akan mengembangkan tingkat dukungan yang kuat untuk organisasi atau pemimpin, dengan perilaku kerja yang efektif seperti kinerja yang lebih baik, komitmen organisasional yang tinggi dan niat keluar dari perusahaan akan melemah.

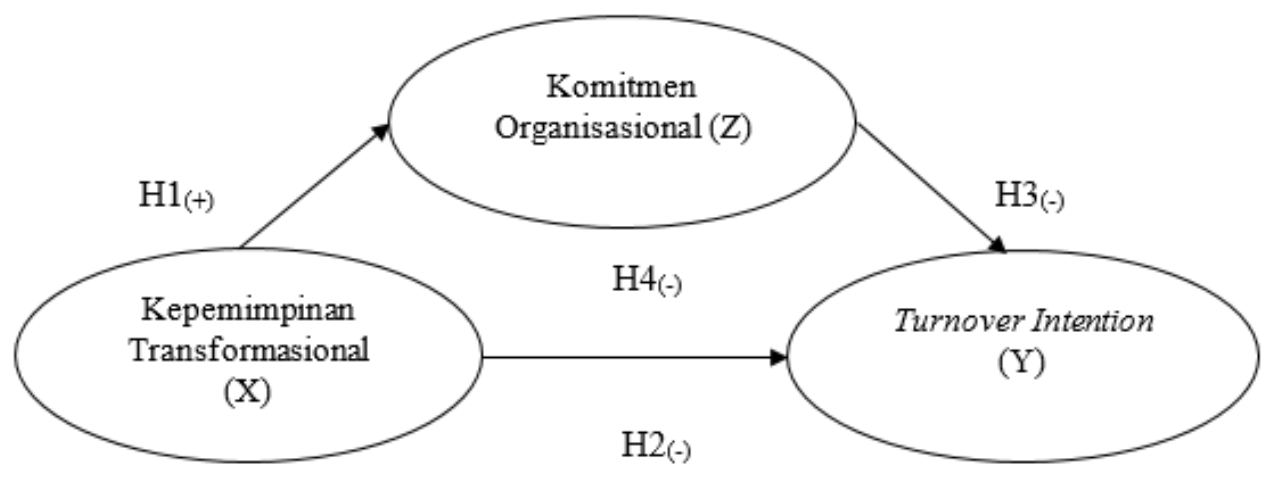

\section{Gambar 1. Kerangka Konseptual Penelitian}

Penelitian yang dilakukan oleh Gathungu et al. (2015) menyatakan bahwa tipe kepemimpinan transformasional berpengaruh positif dan signifikan terhadap komitmen organisasional karyawan. Amin et al. (2018) berpendapat bahwa semakin baik persepsi karyawan terhadap kepemimpinan transformasional maka akan semakin tinggi komitmen karyawannya. Han et al. (2016) juga menyatakan terdapat hubungan yang positif dan signifikan antara kepemimpinan transformasional dengan komitmen organisasional. Hasil yang sama juga dikemukakan oleh Jain \& Taranjeet (2016) menyatakan bahwa pemimpin yang menggambarkan kualitas karismatik lebih mampu meningkatkan komitmen organisasional karyawan. Penelitian yang ditemukan oleh Permatasari \& Saladin (2017) dan Suardani (2018) juga menunjukkan hasil serupa, dimana kepemimpinan transformasional memiliki pengaruh positif dan signifikan terhadap komitmen organisasional karyawan. Hal ini berarti semakin baik kepemimpinan transformasional yang ada, maka semakin meningkat pula komitmen organisasional karyawan.

$\mathrm{H}_{1}$ : kepemimpinan transformasional berpengaruh positif dan signifikan terhadap komitmen organisasional. 
Penelitian Gul et al. (2012) menemukan bahwa gaya kepemimpinan transformasional memiliki hubungan negatif yang signifikan dengan turnover intention. Dari hasil penelitian tersebut dapat dikatakan bahwa persepsi karyawan terhadap gaya kepemimpinan transformasionl secara negatif mempengaruhi keinginan mereka untuk meninggalkan organisasi. Hasil penelitian yang dilakukan oleh Long et al. (2012) menyatakan bahwa meskipun gaya kepemimpinan transformasional yang ditemukan memiliki hubungan negatif dengan turnover intention tetapi korelasi dua variabel ini tidak signifikan. Hasil menunjukkan bahwa hubungan kedua variabel tersebut negatif namun tidak signifikan, hal ini mengindikasikan bahwa meskipun pemimpin sudah mampu menjadi inspirasi dan mampu mendorong karyawan untuk lebih baik namun hal itu tidak mengurangi niat dan perasaan karyawan untuk meninggalkan organisasi.

Hasil serupa juga ditemukan oleh Sartika (2014) yang menyatakan meskipun gaya kepemimpinan transformasional berhubungan negatif namun pengaruhnya belum dapat dikatakan mampu mempengaruhi keinginan keluar karyawan. Penelitian yang dilakukan oleh Yadav \& Misra (2015), Sitorus \& Kasmiruddin (2017) dan Rohmawati (2017) juga mendapatkan hasil bahwa kepemimpinan transformasional berpengaruh negatif terhadap turnover intention karyawan. Hal ini berarti semakin baik kepemimpinan transformasional pada suatu organisasi maka turnover intention karyawan akan menurun

$\mathrm{H}_{2}$ : kepemimpinan transformasional berpengaruh negatif terhadap turnover intention

Beberapa penelitian sebelumnya telah banyak meneliti pengaruh komitmen organisasional terhadap turnover intention karyawan. Hasil penelitian oleh Sartika (2014) menyatakan bahwa komitmen organisasional secara langsung memiliki hubungan negatif signifikan dengan keinginan keluar karyawan, dimana semakin tinggi komitmen organisasional karyawan akan semakin menurunkan keinginan karywan untuk keluar dari pekerjaannya. Pawirosumarto et al. (2017) menunjukkan bahwa variabel komitmen organisasional berpengaruh negatif dan signifikan terhadap turnover intention.

Dari hasil penelitian yang dilakukan oleh Thakre (2015) yang meneliti mengenai hubungan komitmen organisasional terhadap turnover intention ditemukan bahwa adanya hubungan negatif antara turnover intention dengan komitmen organisasional. Hasil yang sama juga ditemukan oleh Rarasanti \& Suana (2016) dimana komitmen organisasional memiliki pengaruh pengaruh negatif terhadap turnover intention. Ahmed \& Nawaz (2015) dalam studinya menunjukkan hasil bahwa ada hubungan negatif yang kuat antara komitmen organisasional dengan turnover intention karyawan, jadi semakin tinggi tingkat komitmen organisasional yang dimiliki para karyawan maka semakin rendah terjadinya tingkat turnover intention karyawan.

$\mathrm{H}_{3}$ : Komitmen organisasional berpengaruh negatif terhadap turnover intention

Gul et al. (2012) menemukan adanya hubungan negatif yang signifikan anatara gaya kepemimpinan transformasional dan transaksional dengan turnover intention dan hubungan positif terhadap komitmen organisasional. Dari hasil penelitian tersebut dapat dikatakan bahwa persepsi karyawan tentang gaya 
kepemimpinan transformasional berpengaruh positif pada komitmen organisasi karyawan. Semakin baik gaya kepemimpinan transformasional akan meningkatkan keinginan karyawan untuk berkomitmen pada organisasi namun komitmen tersebut tidak mempengaruhi keinginan karyawan untuk keluar dari perusahaan.

Hasil yang ditemukan oleh Sartika (2014) keinginan keluar karyawan lebih dipengaruhi oleh komitmen bersinambungan seperti nilai ekonomi yang dirasa dari bertahan di perusahaan dibandingkan dengan komimen afektif dan komitmen normatif seperti persepsi terhadap gaya kepemimpinan transformasional. Berbeda dengan hasil penelitian yang dilakukan oleh Gyensare et al. (2016) bahwa komitmen afektif memiliki dampak positif terhadap pengaruh kepemimpinan transformasional terhadap turnover intention dimana jika organisasi peduli dengan karyawannya maka sebaliknya karyawan akan merawat organisasi tersebut sebagai timbal balik dari ikatan emosional mereka.

Penelitian yang dilakukan Gatling et al. (2016) menemukan bahwa kepemimpinan memiliki pengaruh negatif tidak langsung dan signifikan terhadap turnover karyawan dengan komitmen organisasional sebagai mediasi, dimana hubungan ini dijelaskan oleh sejauh mana karyawan memiliki ikatan emosional dengan organisasi dan sejauh mana karyawan tidak puas dengan pekerjaannya. Dari hasil penelitian yang dilakukan Lim et al. (2017) menunjukkan bahwa kepemimpinan transformasional mempengaruhi turnover intention karyawan secara tidak langsung melalui variabel mediasi komitmen organisasional, dimana kepemimpinan transformasional yang baik akan menghasilkan komitmen dari setiap karyawan dan pada akhirnya mengurangi niat turnover karyawan.

$\mathrm{H}_{4}$ : komitmen organisasional memediasi pengaruh kepemimpinan transformasional terhadap turnover intention.

\section{METODE PENELITIAN}

Penelitian ini digolongkan pada jenis penelitian asosiatif kausalitas. Penelitian ini berlokasi di Ambiente Spa yang beralamat di Jalan Raya Kuta No.98 Tuban, Badung. Lokasi tersebut dipilih karena berdasarkan penelitian awal terlihat adanya permasalahan turnover intention karyawan. Hal ini terindikasi dari tingginya tingkat turnover karywan di Ambiente Spa. Obyek Penelitian dalam penelitian ini adalah kepemimpinan transformasional, komitmen organisasional dan turnover intention karyawan Ambiente Spa. Variabel independen dalam penelitian ini adalah kepemimpinan transformasional. Variabel dependen dalam penelitian ini adalah turnover intention. Variabel Mediasi dalam penelitian ini adalah komitmen organisasional.

Turnover intention dalam penelitian ini merupakan sikap karyawan Ambiente Spa yang berkeinginan meninggalkan perusahaannya dan mencari pekerjaan baru yang dapat diukur dengan tiga indikator, yaitu : Pikiran untuk keluar, Keinginan untuk mencari lowongan pekerjaan lain, Adanya keinginan untuk meninggalkan organisasi dalam waktu dekat. Kepemimpinan transformasional dalam penelitian ini adalah gaya kepemimpinan yang memiliki sifat karismatik serta memiliki peran strategis mengarahkan karyawan untuk 
mencapai tujuan yang telah ditentukan, dengan indikator: Idealized Influence (kharisma), Inspirational motivational, Intellectual Stimulation (stimulasi intelektual), Individualized Consideration (Konsiderasi Individu). Komitmen organisasional dalam penelitian ini adalah kesediaan dan keyakinan yang dimiliki oleh karyawan untuk terlibat pada kegiatan dalam perusahaan sehingga akan timbul perasaan ingin tetap berada atau keluar dari perusahaan tersebut. Terdapat tiga indikator untuk mengukur komitmen organisasional, yaitu : Affective Commitment (komitmen afektif), Continuance Commitment (komitmen bersinambung), Normative Commitment (komitmen normatif),

Data kuantitatif dalam penelitian ini adalah jumlah karyawan, data turnover karyawan yang diperoleh dari perusahaan dan skor jawaban kuisioner. Data kualitatif pada penelitian ini adalah sejarah perusahaan dan struktur organisasi yang diperoleh dari perusahaan. Sumber primer pada penelitian ini adalah responden atau karyawan Ambiente Spa menggunakan kuesioner dan wawancara, dalam wawancara peneliti mendapat jawaban langsung karyawan dan melalui kuesioner responden memberikan skor pada pernyataan dari setiap variabel penelitian. Sumber sekunder dalam penelitian ini adalah pihak manager Ambiente $S p a$, seperti jumlah karyawan, gambaran umum perusahaan serta tingkat turnover karyawan.

Populasi pada penelitian ini adalah seluruh karyawan Ambiente Spa yaitu sebanyak 100 orang karyawan, tidak termasuk 2 orang pimpinan perusahaan, sebab penelitian ini ingin meneliti variabel gaya kepemimpinan transformasional. Metode penentuan sampel yang digunakan adalah teknik sampel jenuh yaitu seluruh anggota populasi digunakan sebagai sampel. Sampel dalam penelitian ini adalah seluruh karyawan Ambiente Spa yang berjumlah 100 orang. Metode pengumpulan data yang digunakan dalam penelitian ini dengan cara Wawancara digunakan sebagai teknik pengumpulan data dengan melakukan tanya jawab secara langsung kepada 8 orang karyawan Ambiente Spa mengenai kepemimpinan transformasional, komitmen organisasional dan turnover intention yang ada dalam perusahaan dan penyebaran kuesioner.

\section{HASIL DAN PEMBAHASAN}

Ambiente Spa sebuah perusahaan swasta yang bergerak dibidang penyedia jasa berbasis terapi dan relaksasi, yang berdiri sejak tahun 2003. Perusahaan ini beralamat di Jalan Raya Kuta No.98 Tuban, Bali. Awal mula tercetusnya Ambiente spa, diawali dengan bertemunya dua orang sahabat lama yaitu Bapak Freddy Sulaeman yang merupakan investor bisnis dan bapak Wibisana Yostiadi yang merupakan dokter medis dan ahli terapis pada tahun 2002. Tak lama pada 15 oktober 2003 terbentuklah Ambiente Reflexology yang terletak di Kuta Square, Kuta, Bali, seiring berjalannya waktu Ambiente Spa telah memiliki kantor pribadi di Tuban, Bali. Ambiente Spa memiliki beberapa jenis perawatan yang ditawarkan seperti massage, body care, reflexology, remedy, aromatherapy and hydrotherapy.

Karakteristik responden dimana karyawan perempuan lebih dominan karena perusahaan ini para pekerja sebagian besar berjenis kelamin perempuan dengan 
keseluruhan persentase 56 persen atau sebanyak 56 orang dan sisanya sebesar 44 persen atau 44 orang berjenis kelamin laki - laki, hal ini dikarenakan untuk posisi yang membutuhkan banyak orang seperti therapist dan receptionist memerlukan tenaga perempuan. Usia sebagian besar karyawan adalah 25 sampai 34 tahun dengan persentase 38 persen atau sebanyak 38 orang karena dalam industri jasa khususnya Spa memerlukan tenaga ekstra dalam penjualan jasanya sehingga memerlukan karyawan dengan usia muda.

Tabel 2.

Karakteristik Responden

\begin{tabular}{|c|c|c|c|}
\hline Kriteria & Klasifikasi & $\begin{array}{l}\text { Jumlah } \\
\text { (orang) }\end{array}$ & $\begin{array}{c}\text { Persentase } \\
(\%)\end{array}$ \\
\hline \multirow{2}{*}{ Jenis Kelamin } & Laki - Laki & 44 & 44 \\
\hline & Perempuan & 56 & 56 \\
\hline \multirow{5}{*}{ Usia } & Jumlah & 100 & 100 \\
\hline & 19-24 Tahun & 36 & 36 \\
\hline & 25-34 Tahun & 38 & 38 \\
\hline & 35-40 Tahun & 18 & 18 \\
\hline & $>$ 40Tahun & 8 & 8 \\
\hline \multirow{4}{*}{$\begin{array}{l}\text { Pendidikan } \\
\text { terakhir }\end{array}$} & Jumlah & 100 & 100 \\
\hline & SMA/SMK & 65 & 65 \\
\hline & Diploma & 30 & 30 \\
\hline & $\mathrm{S} 1$ & 5 & 5 \\
\hline \multirow{5}{*}{ Masa kerja } & Jumlah & 100 & 100 \\
\hline & $<1$ Tahun & 20 & 20 \\
\hline & 1-3 Tahun & 63 & 63 \\
\hline & $>4$ Tahun & 17 & 17 \\
\hline & Jumlah & 100 & 100 \\
\hline
\end{tabular}

Sumber : Data diolah, 2019

Pendidikan terakhir responden didominasi lulusan SMA/SMK dengan persentase 65 persen atau 65 orang, sedangkan lulusan Diploma sebesar 30 persen dan lulusan S1 sebesar 5 persen. Banyaknya lulusan SMA/SMK yang dipekerjakan karena pada posisi seperti therapist, cleaning service, security dan driver tidak memerlukan pendidikan yang tinggi melainkan keinginan untuk belajar. Sedangkan untuk lulusan Diploma ditempatkan pada posisi general cashier, storekeeper, book keeper dan purcashing. Lulusan S1 menduduki posisi assistant human resource manager, general administrative \& graphis supervisor. Karywan dengan masa kerja 1-3 tahun lebih mendominasi bila dibandingkan dengan yang bekerja dibawah 1 tahun maupun diatas 4 tahun karena dalam beberapa posisi dalam industri jasa khususnya spa memerlukan karyawan yang masih tergolong muda.

Uji reliabilitas pada masing-masing variabel berada pada titik diatas 0,60 yang ditunjukkan pada hasil Cronbach's Alpha, maka dapat dikatakan seluruh instrumen telah memenuhi syarat reliabilitas. Seluruh instrumen variabel penelitian berupa kepemimpinan transformasional, komitmen organisasional dan turnover intention telah memenuhi syarat uji validitas yang dimana nilai skor total 
Pearson's Correlation masing-masing instrumen berada diatas 0,30, maka instrumen layak digunakan menjadi alat ukur variabel-variabel tersebut.

Tabel 3.

Hasil Uji Reliabilitas

\begin{tabular}{llcc}
\hline No. & \multicolumn{1}{c}{ Variabel } & Cronbach's Alpha & Keterangan \\
\hline 1. & Kepemimpinan transformasional $(\mathrm{X})$ & 0,978 & Reliabel \\
2. & Komitmen organisasional $(\mathrm{Z})$ & 0,980 & Reliabel \\
3. & Turnover intention $(\mathrm{Y})$ & 0,974 & Reliabel \\
\hline
\end{tabular}

Sumber: Data diolah, 2019

Turnover Intention yang dimiliki karyawan termasuk dalam kriteria cukup tinggi, terlihat secara keseluruhan rata-rata jawaban responden memiliki nilai sebesar 2,81. Nilai rata-rata tertinggi terdapat pada pernyataan saya memiliki pemikiran untuk pindah kerja pada waktu yang akan datang dengan nilai rata-rata sebesar 2,93. Hal tersebut menunjukkan sebagian besar responden masih ingin tetap bekerja di perusahaan. Kepemimpinan transformasional yang dirasakan oleh karyawan termasuk dalam kriteria cukup baik dengan nilai rata-rata sebesar 3,22 yang berarti kemampuan pemimpin dalam mempengaruhi bawahannya tergolong cukup baik. Nilai rata-rata terendah terdapat pada penyataan "pemimpin saya membangun rasa hormat saya dengan bijak" yaitu sebesar 3,05. Hal tersebut menandakan bahwa karyawan menganggap pemimpin harus bisa membangun rasa hormat karyawan dengan bijak agar dapat membuat karyawan bekerja lebih baik.

Berdasarkan Tabel 4. variabel komitmen organisasional diukur menggunakan 18 butir pernyataan yang berhubungan dengan komitmen afektif, komitmen normatif dan komitmen bersinambung. Komitmen organisasional yang dimiliki karyawan tergolong cukup tinggi, karena secara keseluruhan rata-rata jawaban responden memiliki nilai sebesar 3,09. Pernyataan "Saya tidak mempunyai rasa memiliki perusahaan ini.", diperoleh nilai rata-rata terendah sebesar 2,82. Hal tersebut menunjukkan perusahaan harus mampu meningkatkan rasa memiliki karyawan agar timbul perasaan ingin tetap berada dalam perusahaan.

Berdasarkan Tabel 5. besarnya nilai Kolmogorov-Smirnov adalah sebesar 0,934 dan 1,124, sedangkan nilai Asymp. Sig. (2-tailed) sebesar 0,134 dan 0,095. Hasil tersebut mengindikasikan bahwa model persamaan regresi tersebut memiliki distribusi normal, karena nilai Asymp. Sig. (2-tailed) sebesar 0,134 dan 0,095 itu lebih besar dari alpha 0,05 .

Tidak terdapat variabel bebas pada Tabel 6. yang memiliki nilai tolerance kurang dari 0,10 dan juga tidak ada variabel bebas yang memiliki nilai VIF lebih dari 10. Maka dari pada itu model regresi bebas dari gejala multikoleniaritas. Masing -masing model memiliki nilai variabel-variabel tersebut lebih besar dari 0,05 yang berarti tidak terdapat pengaruh variabel bebas terhadap absolute residual. Dengan demikian, model regresi 2 yang dibuat tidak mengandung gejala heterokedastisitas. 
E-Jurnal Manajemen, Vol. 9, No. 4, 2020 : 1445-1464

Tabel 4.

Hasil Uji Validitas

\begin{tabular}{|c|c|c|c|c|}
\hline No. & Variabel & Instrumen & $\begin{array}{c}\text { Pearson's } \\
\text { Correlation }\end{array}$ & Keterangan \\
\hline \multirow{7}{*}{1.} & \multirow{7}{*}{ Turnover intention } & Y1 & 0,953 & Valid \\
\hline & & Y2 & 0,961 & Valid \\
\hline & & Y3 & 0,945 & Valid \\
\hline & & Y4 & 0,911 & Valid \\
\hline & & Y5 & 0,950 & Valid \\
\hline & & Y6 & 0,952 & Valid \\
\hline & & $\mathrm{X} 1$ & 0,909 & Valid \\
\hline \multirow{13}{*}{2.} & \multirow{13}{*}{$\begin{array}{l}\text { Kepemimpinan } \\
\text { Transfrmasional }\end{array}$} & X2 & 0,883 & Valid \\
\hline & & X3 & 0,894 & Valid \\
\hline & & $\mathrm{X} 4$ & 0,877 & Valid \\
\hline & & X5 & 0,892 & Valid \\
\hline & & X6 & 0,824 & Valid \\
\hline & & $\mathrm{X} 7$ & 0,898 & Valid \\
\hline & & X8 & 0,940 & Valid \\
\hline & & X9 & 0,930 & Valid \\
\hline & & X10 & 0,868 & Valid \\
\hline & & X11 & 0,810 & Valid \\
\hline & & $\mathrm{X} 12$ & 0,767 & Valid \\
\hline & & X13 & 0,840 & Valid \\
\hline & & X14 & 0,889 & Valid \\
\hline \multirow{19}{*}{3.} & \multirow{19}{*}{ Komitmen organisasional } & X15 & 0,930 & Valid \\
\hline & & $\mathrm{Z} 1$ & 0,889 & Valid \\
\hline & & Z2 & 0,864 & Valid \\
\hline & & $\mathrm{Z3}$ & 0,876 & Valid \\
\hline & & Z4 & 0,825 & Valid \\
\hline & & Z5 & 0,882 & Valid \\
\hline & & Z6 & 0,887 & Valid \\
\hline & & Z7 & 0,856 & Valid \\
\hline & & Z8 & 0,902 & Valid \\
\hline & & Z9 & 0,881 & Valid \\
\hline & & Z10 & 0,890 & Valid \\
\hline & & Z11 & 0,859 & Valid \\
\hline & & Z12 & 0,895 & Valid \\
\hline & & Z13 & 0,845 & Valid \\
\hline & & Z14 & 0,905 & Valid \\
\hline & & Z15 & 0,911 & Valid \\
\hline & & Z16 & 0,931 & Valid \\
\hline & & Z17 & 0,722 & Valid \\
\hline & & Z18 & 0,880 & Valid \\
\hline
\end{tabular}

Sumber : Data diolah, 2019

Tabel 5.

Hasil Uji Normalitas

\begin{tabular}{lcc}
\hline & Unstandardized Residual & Unstandardized Residual \\
\hline $\mathrm{N}$ & 100 & 100 \\
Kolmogorov-Smirnov Z & 0,934 & 1,124 \\
Asymp. Sig. (2-tailed) & 0,134 & 0,095 \\
\hline Sumber : Data diolah, 2019 & &
\end{tabular}

Sumber: Data diolah, 2019 
Tabel 6.

Hasil Uji Multikolinieritas

\begin{tabular}{lcc}
\hline \multirow{2}{*}{ Model } & \multicolumn{2}{c}{ Collinearity Statistics } \\
\cline { 2 - 3 } & Tolerance & VIF \\
\hline Kepemimpinan & 0,309 & 3,232 \\
Transformasional & 0,309 & 3,232 \\
Komitmen Organisasional & &
\end{tabular}

Tabel 7.

Hasil Uji Heteroskedastisitas Persamaan 1

\begin{tabular}{|c|c|c|c|c|c|}
\hline \multirow[t]{2}{*}{ Model } & \multicolumn{2}{|c|}{$\begin{array}{c}\text { Unstandardized } \\
\text { Coefficients }\end{array}$} & \multirow{2}{*}{$\begin{array}{c}\begin{array}{c}\text { Standardized } \\
\text { Coefficients }\end{array} \\
\text { Beta } \\
\end{array}$} & \multirow[b]{2}{*}{$\mathbf{t}$} & \multirow[b]{2}{*}{ Sig. } \\
\hline & B & Std. Error & & & \\
\hline (Constant) & $-1,249$ & 1,894 & & $-0,659$ & 0,511 \\
\hline $\begin{array}{l}\text { Kepemimpinan } \\
\text { Transformasional }\end{array}$ & 0,070 & 0,038 & 0,183 & 1,838 & 0,069 \\
\hline
\end{tabular}

Sumber : Data diolah, 2019

Tabel 8.

Hasil Uji Heteroskedastisitas Persamaan 2

\begin{tabular}{|c|c|c|c|c|c|}
\hline \multirow[t]{2}{*}{ Model } & \multicolumn{2}{|c|}{$\begin{array}{c}\text { Unstandardized } \\
\text { Coefficients }\end{array}$} & \multirow{2}{*}{$\begin{array}{c}\begin{array}{c}\text { Standardized } \\
\text { Coefficients }\end{array} \\
\text { Beta } \\
\end{array}$} & \multirow[b]{2}{*}{$\mathbf{t}$} & \multirow[b]{2}{*}{ Sig. } \\
\hline & B & Std. Error & & & \\
\hline (Constant) & $-0,474$ & 1,059 & & $-0,447$ & 0,656 \\
\hline $\begin{array}{l}\text { Kepemimpinan } \\
\text { Transformasional }\end{array}$ & 0,057 & 0,024 & .394 & 1,126 & 0,122 \\
\hline $\begin{array}{l}\text { Komitmen } \\
\text { Organisasional }\end{array}$ & $-0,005$ & 0,032 & $-0,028$ & $-0,168$ & 0,867 \\
\hline
\end{tabular}

Sumber : Data diolah, 2019

Tabel 9.

Hasil Analisis Jalur Pada Struktur 1

\begin{tabular}{|c|c|c|c|c|c|}
\hline \multirow[t]{2}{*}{ Model } & \multicolumn{2}{|c|}{ Unstandardized Coefficients } & \multirow{2}{*}{$\begin{array}{c}\begin{array}{c}\text { Standardized } \\
\text { Coefficients }\end{array} \\
\text { Beta }\end{array}$} & \multirow[t]{2}{*}{$\mathbf{t}$} & \multirow[t]{2}{*}{ Sig. } \\
\hline & B & Std. Error & & & \\
\hline (Constant) & 25,198 & 2,121 & & 11,880 & 0,000 \\
\hline $\begin{array}{l}\text { Kepemimpinan } \\
\text { transformasional }\end{array}$ & 0,629 & 0,043 & 0,831 & 14,788 & 0,000 \\
\hline $\mathrm{R}^{2} \quad: 0,691$ & & & & & \\
\hline
\end{tabular}

Nilai koefisien regresi pada analisis jalur struktur 1, variabel kepemimpinan transformasional bernilai positif dengan nilai signifikansi uji t kurang dari 0,05 . Hal ini menunjukkan bahwa variabel kepemimpinan transformasional memiliki pengaruh positif yang signifikan terhadap variabel komitmen organisasional. 
Besarnya pengaruh tersebut ditunjukkan oleh nilai determinasi total ( $R$ Square) sebesar 0,691 mempunyai arti bahwa sebesar 69,1\% variabel komitmen organisasional dipengaruhi oleh variabel kepemimpinan transformasional, sedangkan sisanya sebesar $30,9 \%$ dijelaskan oleh faktor lain yang tidak dimasukan dalam model.

Nilai koefisien regresi masing-masing variabel bebas bernilai negatif dengan nilai signifikansi uji t kurang dari 0,05 . Hal ini menunjukkan bahwa semua variabel bebas memiliki pengaruh negatif terhadap variabel terikat. Besarnya pengaruh variabel bebas terhadap variabel terikat yang ditunjukkan oleh nilai determinasi total ( $R$ Square) sebesar 0,622 mempunyai arti bahwa sebesar $62,2 \%$ variabel turnover intention dipengaruhi oleh variabel kepemimpinan transformasional dan komitmen organisasional, sedangkan sisanya sebesar 37,8\% dijelaskan oleh faktor lain yang tidak dimasukkan ke dalam model. Nilai determinasi total sebesar 0,884mempunyai arti bahwa sebesar $88,4 \%$ variabel turnover intention dipengaruhi oleh variabel gaya kepemimpinan transformasional dan komitmen organisasional, sedangkan sisanya sebesar 11,6\% dipengaruhi oleh faktor lain yang tidak dimasukkan ke dalam model penelitian ini.

Tabel 10.

Hasil Analisis Jalur Pada Struktur 2

\begin{tabular}{|c|c|c|c|c|c|}
\hline \multirow{2}{*}{ Model } & \multicolumn{2}{|c|}{$\begin{array}{c}\text { Unstandardized } \\
\text { Coefficients }\end{array}$} & \multirow{2}{*}{$\begin{array}{c}\begin{array}{c}\text { Standardized } \\
\text { Coefficients }\end{array} \\
\text { Beta }\end{array}$} & \multirow[t]{2}{*}{$\mathbf{t}$} & \multirow[t]{2}{*}{ Sig. } \\
\hline & B & Std. Error & & & \\
\hline (Constant) & 39,121 & 2,152 & & 18,178 & 0,000 \\
\hline $\begin{array}{l}\text { Kepemimpinan } \\
\text { transformasional }\end{array}$ & $-0,181$ & 0,050 & $-0,409$ & $-3,645$ & 0,000 \\
\hline $\begin{array}{l}\text { Komitmen } \\
\text { organisasional }\end{array}$ & $-0,243$ & 0,066 & $-0,415$ & $-3,697$ & 0,000 \\
\hline $\mathrm{R}^{2} \quad: 0.622$ & & & & & \\
\hline
\end{tabular}

Tabel 11.

Pengaruh Langsung, Pengaruh Tidak Langsung Kepemimpinan transformasional(X), Terhadap Komitmen organisasional (Z) dan Turnover intention (Y)

\begin{tabular}{lccc}
\hline $\begin{array}{c}\text { Pengaruh } \\
\text { variabel }\end{array}$ & $\begin{array}{c}\text { Pengaruh } \\
\text { langsung }\end{array}$ & $\begin{array}{c}\text { Pengaruh tidak } \\
\text { langsung melalui } Z\end{array}$ & Pengaruh Total \\
\hline $\mathrm{X} \rightarrow \mathrm{Z}$ & 0,831 & & 0,831 \\
$\mathrm{X} \rightarrow \mathrm{Y}$ & $-0,409$ & $-0,345$ & $-0,754$ \\
$\mathrm{Z} \rightarrow \mathrm{Y}$ & $-0,415$ & & $-0,415$ \\
\hline$S$
\end{tabular}

Sumber: Data primer diolah, 2019

Pengaruh langsung variabel kepemimpinan transformasional terhadap komitmen organisasional adalah sebesar 0,831. Pengaruh langsung variabel kepemimpinan transformasional terhadap turnover intention sebesar $-0,409$. Pengaruh langsung variabel komitmen organisasional terhadap turnover intention sebesar -0,415. Hal ini berarti bahwa variabel turnover intention lebih besar 
dipengaruhi oleh variabel komitmen organisasional dibandingkan variabel kepemimpinan transformasional. Sedangkan pengaruh tidak langsung variabel kepemimpinan transformasional terhadap turnover intention melalui komitmen organisasional sebesar -0,345. Jadi dapat disimpulkan bahwa pengaruh total kepemimpinan transformasional terhadap komitmen organisasional lebih besar dibandingkan pengaruh total kepemimpinan transformasional terhadap turnover intention melalui komitmen organisasional.

Besarnya pengaruh kepemimpinan transformasional terhadap komitmen organisasional adalah sebesar 0,831. Angka ini menunjukkan bahwa kepemimpinan transformasional berpengaruh signifikan terhadap komitmen organisasional sebesar 83,1 persen dan sisanya 16,9 persen dipengaruhi oleh faktor lain diluar model Besarnya pengaruh kepemimpinan transformasional terhadap turnover intention adalah sebesar -0,409. Angka ini menunjukkan bahwa kepemimpinan transformasional berpengaruh negatif dan signifikan terhadap turnover intention sebesar $-40,9$ persen, sedangkan sisanya $-59,1$ persen dipengaruhi oleh faktor lain diluar model. Besarnya pengaruh komitmen organisasional terhadap turnover intention adalah sebesar -0,415. Angka ini menunjukkan bahwa komitmen organisasional berpengaruh negatif dan signifikan terhadap turnover intention sebesar $-41,5$ persen, sendangkan sisanya $-58,5$ persen dipengaruhi oleh faktor lain diluar model.

Nilai signifikansi untuk pengaruh variabel kepemimpinan transformasional sebesar 0,000 terhadap variabel komitmen organisasional. Hasil tersebut membuktikan bahwa variabel kepemimpinan transformasional berpengaruh positif dan signifikan terhadap komitmen organisasional di Ambiente Spa, dimana semakin baik seorang pemimpin menerapkan gaya kepemimpinan transformasional maka akan semakin tinggi komitmen karyawan terhadap perusahaan. Hal ini menandakan bahwa kepemimpinan transformasional mampu menimbulkan komitmen organisasional pada diri karyawan.

Hal ini sejalan dengan hasil penelitian yang dilakukan oleh Gathungu et al. (2015) menyatakan bahwa tipe kepemimpinan transformasional berpengaruh positif dan signifikan terhadap komitmen organisasional karyawan. Amin et al. (2018) berpendapat bahwa semakin baik persepsi karyawan terhadap kepemimpinan transformasional maka akan semakin tinggi komitmen organisasinya. Han et al. (2016) juga menyatakan terdapat hubungan yang positif dan signifikan antara kepemimpinan transformasional terhadap komitmen organisasional.

Hasil yang sama juga dikemukakan oleh Jain \& Taranjeet (2016) menyatakan bahwa pemimpin yang menggambarkan kualitas karismatik lebih mampu meningkatkan komitmen organisasional karyawan. Penelitian yang ditemukan oleh Permatasari \& Saladin (2017) dan Suardani (2018) juga menunjukkan hasil serupa, dimana kepemimpinan transformasional memiliki pengaruh positif dan signifikan terhadap komitmen organisasional karyawan. Hal ini berarti semakin baik kepemimpinan transformasional yang ada, maka semakin meningkat pula komitmen organisasional karyawan.

Hasil analisis menunjukkan bahwa kepemimpinan transformasional berpengaruh negatif dan signifikan terhadap turnover intention. Ini menandakan 
bahwa semakin baik kepemimpinan transformasional dalam memimpin, maka keinginan karyawan di Ambiente Spa akan semakin menurun. Hal ini sejalan dengan hasil penelitian yang dilakukan oleh Penelitian yang dilakukan oleh Penelitian Gul et al. (2012) menemukan adanya hubungan negatif yang signifikan anatara gaya kepemimpinan transformasional terhadap turnover intention. Dari hasil penelitian tersebut dapat dikatakan bahwa persepsi karyawan terhadap gaya kepemimpinan transformasionl secara negatif mempengaruhi keinginan mereka untuk meninggalkan organisasi. Hasil penelitian yang dilakukan oleh Yadav \& Misra (2015), Sitorus \& Kasmiruddin (2017) dan Rohmawati (2017) juga mendapatkan hasil bahwa kepemimpinan transformasional berpengaruh negatif terhadap turnover intention karyawan.

Hasil analisis hipotesis menunjukkan bahwa komitmen organisasional berpengaruh negatif dan signifikan terhadap turnover intention, nilai signifikansi pengaruh variabel komitmen organisasional terhadap turnover intention sebesar $0,000<0,05$. Jadi bila karyawan telah memiliki komitmen organisasional yang tinggi, keinginannya untuk meninggalkan perusahaan akan berkurang. Hal ini sejalan dengan penelitian yang dilakukan oleh Amin et al. (2018) menyatakan bahwa komitmen organisasional secara langsung memiliki hubungan negatif signifikan dengan keinginan keluar karyawan, dimana semakin tinggi komitmen organisasional karyawan akan semakin menurunkan keinginan karywan untuk keluar dari pekerjaannya.

Pawirosumarto et al. (2017) menunjukkan bahwa variabel komitmen organisasional berpengaruh negatif dan signifikan terhadap turnover intention. Dari hasil penelitian yang dilakukan oleh Thakre (2015) yang meneliti mengenai hubungan komitmen organisasional terhadap turnover intention ditemukan bahwa adanya hubungan negatif antara turnover intention dengan komitmen organisasional. Hasil yang sama juga ditemukan oleh Rarasanti \& Suana (2016) dimana komitmen organisasional memiliki pengaruh pengaruh negatif terhadap turnover intention. Ahmed \& Nawaz (2015) dalam studinya menunjukkan hasil bahwa ada hubungan negatif yang kuat antara komitmen organisasional dengan turnover intention karyawan, jadi semakin tinggi tingkat komitmen organisasional yang dimiliki para karyawan maka semakin rendah terjadinya tingkat turnover intention karyawan.

Hasil analisis hipotesis memperoleh hasil bahwa nilai koefisien pengaruh tidak langsung untuk hipotesis ini sebesar $-0,345$ atau 34,5\%. Hasil tersebut menunjukkan bahwa komitmen organisasional memiliki peran mediasi dalam pengaruh negatif dan signifikan kepemimpinan transformasional terhadap turnover intention. Jadi semakin baik kepemimpinan transformasional di Ambiente Spa, maka semakin tinggi pula komitmen organisasional karyawan di Ambiente Spa dan keinginan karyawan untuk keluar dari perusahaan pun menjadi semakin rendah.

Hasil penelitian ini sejalan dengan Hasil penelitian yang dilakukan oleh Gul et al. (2012) menemukan adanya hubungan negatif yang signifikan anatara gaya kepemimpinan transformasional dan transaksional terhadap turnover intention dan hubungan positif terhadap komitmen organisasi. Dari hasil penelitian tersebut dapat dikatakan bahwa persepsi karyawan tentang gaya kepemimpinan 
transformasional berpengaruh positif pada komitmen organisasi karyawan. Semakin baik gaya kepemimpinan transformasional akan meningkatkan keinginan karyawan untuk berkomitmen pada organisasi namun komitmen tersebut tidak mempengaruhi keinginan karyawan untuk keluar dari perusahaan.

Hasil serupa juga ditemukan oleh Amin et al. (2018) komitmen organisasi tidak memediasi hubungan antara gaya kepemimpinan transformasional terhadap keinginan keluar karyawan. keinginan keluar karyawan lebih dipengaruhi oleh komitmen bersinambungan seperti nilai ekonomi yang dirasa dari bertahan di perusahaan dibandingkan dengan komimen afektif dan komitmen normatif seperti persepsi terhadap gaya kepemimpinan transformasional.

Berbeda dengan hasil penelitian yang dilakukan oleh Gyensare et al. (2016) bahwa komitmen afektif memiliki dampak positif terhadap pengaruh kepemimpinan transformasional terhadap turnover intention dimana jika organisasi peduli dengan karyawannya maka sebaliknya karyawan akan merawat organisasi tersebut sebagai timbal balik dari ikatan emosional mereka. Penelitian yang dilakukan Gatling et al. (2016) menemukan bahwa kepemimpinan memiliki pengaruh negatif tidak langsung dan signifikan terhadap turnover karyawan dengan komitmen organisasional sebagai mediasi, dimana hubungan ini dijelaskan oleh sejauh mana karyawan memiliki ikatan emosional dengan organisasi dan sejauh mana karyawan tidak puas dengan pekerjaannya. Dari hasil penelitian yang dilakukan Lim et al. (2017) menunjukkan bahwa kepemimpinan transformasional mempengaruhi turnover intention karyawan secara tidak langsung melalui variabel mediasi komitmen organisasional, dimana kepemimpinan transformasional yang baik akan menghasilkan komitmen dari setiap karyawan dan pada akhirnya mengurangi niat turnover karyawan.

Responden sangat setuju bahwa kepemimpinan transformasional mampu meningkatkan komitmen organisasional. Indikator dari gaya kepemimpinan transformasional, yaitu: stimulasi intelektual sangat diperlukan untuk meningkatkan komitmen organisasional. Bila pemimpin menggunakan kepemimpinan transformasional, maka pemimpin tersebut akan mampu memberi pendekatan terhadap karyawan agar lebih kreatif dan inovatif dalam menyelesaikan masalah, kemudian secara langsung akan berpengaruh terhadap komitmen organisasional karyawan di perusahaan. Jadi penting bagi pimpinan perusahaan untuk selalu menggunakan kepemimpinan transformasional. Peningkatan komitmen organisasional dalam perusahaan akan dapat menurunkan turnover intention karyawan. Pernyataan responden tentang saya merasa bahwa saya memiliki sedikit pilihan untuk meninggalkan organisasi ini memiliki ratarata tertinggi. Hal ini menunjukkan bahwa setiap karyawan di Ambiente Spa menyadari apabila mereka keluar dari perusahaan akan ada resiko yang didapat. Menurut responden hal tersebut akan mampu meningkatkan komitmen organisasional yang secara langsung mengurangi turnover intention karyawan.

\section{SIMPULAN}

Kepemimpinan transformasional berpengaruh positif dan signifikan terhadap komitmen organisasional karyawan Ambiente Spa, dimana semakin baik 
seorang pemimpin menerapkan gaya kepemimpinan transformasional maka akan semakin tinggi komitmen karyawan terhadap perusahaan. Kepemimpinan transformasional berpengaruh negatif dan signifikan terhadap turnover intention karyawan Ambiente Spa, hal ini menunjukkan semakin baik kepemimpinan transformasional maka mengurangi tingkat turnover intention karyawan Ambiente Spa.

Komitmen organisasional berpengaruh negatif dan signifikan terhadap turnover intention karyawan Ambiente Spa, hal ini menunjukkan bahwa komitmen organisasional yang rendah akan menyebabkan tingginya turnover intention karyawan, begitu juga sebaliknya komitmen organisasional yang tinggi secara langsung dapat menyebabkan rendahnya turnover intention karyawan. Komitmen organisasional merupakan variabel mediasi pengaruh antara kepemimpinan transformasional terhadap turnover intention karyawan Ambiente $S p a$, hal ini menunjukkan bahwa semakin tinggi kepemimpinan transformasional di perusahaan, maka semakin tinggi juga komitmen organisasional karyawan dan turnover intention karyawan pun menjadi semakin rendah.

Berdasarkan hasil yang diperoleh kepemimpinan transformasional dan komitmen organisasional memiliki pengaruh yang negatif signifikan terhadap turnover intention karyawan Ambiente Spa, ini menunjukkan bahwa pihak Ambiente Spa disarankan untuk lebih membangun rasa hormat karyawan dengan bijak agar karyawan tidak memiliki niat untuk pindah bekerja pada waktu yang akan datang. Bagi penelitian selanjutnya diharapkan mampu menambah variabelvariabel yang dapat mempengaruhi turnover intention, serta mampu untuk memperluas ruang lingkup penelitian yang tidak hanya terbatas pada Ambiente $S p a$, atau dapat juga mengganti lokasi penelitian yang tidak hanya terfokus pada suatu lokasi penelitian, sehingga memberikan suatu pandangan yang lebih dan mampu diimplementasikan secara umum.

\section{REFERENSI}

Ahmed, M., \& Nawaz, N. (2015). Impact of Organizational Commitment on Employee Turnover: A Case Study of Pakistan International Airlines ( PIA ). Industrial Engineering Letters, 5(8), 57-70.

Amin, W., Akram, U., Shahzad, F., \& Amir, M. (2018). Impact of Transformation Leadership on Affective Employee's Commitment. European Online Journal of Natural and Social Sciences, 7(1), 48-57.

Andini, O. P., Sunuharyo, B. S., \& Utami, H. N. (2018). Pengaruh Kepuasan Kerja terhadap Stres Kerja dan Turnover Intention Karyawan (Studi Pada Karyawan PT Indolakto Factory Pandaan). Jurnal Administrasi Bisnis, 54(1), $1-20$.

Azeez, R. O., Jayeoba., F. I., \& Adeoye., A. O. (2016). Job Satisfaction, Turnover Intention and Organizational Commitment. Journal of Management Research, 8(2), 102-114.

Dariush, L., Ghobad, C., Parivash, V., \& Erfan, M. (2016). Leadership Styles 
Facilitating Organizational Commitment of Employees. International Journal of Economics, Commerce and Management, 4(5), 640-655.

El-Badawy, T. A., \& Bassiouny, M. (2014). Employee Engagement as a Mediator between Transformational Leadership and Intention to Quit. Journal of Management, 12(1), 37-50.

Gathungu, E. W. M., Iravo, M. A., \& Namusonge, G. S. (2015). Transformational Leadership and Employee's Commitment: Empirical Review. IOSR Journal Of Humanities And Social Science (IOSR-JHSS), 20(7), 01-07.

Gatling, A., Kang, H. J. A., \& Kim, J. S. (2016). The Effects of Authentic Leadership and Organizational Commitment on Turnover Intention. Leadership \& Organization Development Journal, 37(2), 181-199.

Gul, S., Ahmad, B., Ur Rehman, S., Shabir, N., \& Razzaq, N. (2012). Leadership Styles, Turnover Intention and The Mediating Role of Organizational Commitment. Information and Knowledge Management, 2(7), 44-51.

Gyensare, M. A., Anku-Tsede, O., Sanda, M.-A., \& Okpoti, C. A. (2016). Transformational Leadership and Employee Turnover Intention: The Mediating Role of Affective Commitment. World Journal of Entrepreneurship, Management and Sustainable Development, 12(4), 243266.

Han, S. H., Gaeun, S., Seung, W. Y., \& Dong, Y. Y. (2016). Transformational Leadership and Knowledge Sharing Mediating Roles of Employee's Empowerment, Commitment and Citizenship Behaviors. Journal of Workplace Learning, 28(3), 130-149.

Jain, P., \& Taranjeet, D. (2016). The Influence of Transformational Leadership and Emotional Intelligence on Organizational Commitment. Journal of Commerce \& Management Thought, 7(3), 586-598.

Khan, M. A. S., \& Du, J. (2015). An Empirical Study of Turnover Intentions in Call Centre Industry of Pakistan. Journal of Human Resource And Sustainability Studies, 2(2), 206-214.

Ksama, I., \& Wibawa, I. (2016). Pengaruh Leader-Member Exchange, Role Stress dan Perceived Organizational Support Terhadap Turnover Intention Pada Karyawan Hotel Griya Santrian Sanur. E-Jurnal Manajemen Unud, 5(10), 6174-6200.

Lim, A. J. P., Loo, J. T. K., \& Pey, H. . (2017). The impact of leadership on turnover intention: The mediating role of organizational commitment and job satisfaction. Journal of Applied Structural Equation Model, 1(1), 27-41.

Long, C. S., Thean, L. Y., Ismail, W. K. W., \& Jusoh, A. (2012). Leadership Styles and Employees Turnover Intention: Exploratory Study Of Academic Staff In A Malaysian College. World Applied Sciences Journal, 10(4), 575581. 
Pawirosumarto, S., Setiawan, K., Setyadi, \& Elmi, F. (2017). the Effect of Organizational Commitment Toward Turnover Intention At Narada School, Indonesia. Russian Journal of Agricultural and Socio-Economic Sciences, 62(2), 55-66. https://doi.org/10.18551/rjoas.2017-02.07

Peachey, J. W., Burton, L. J., \& Wells., J. E. (2015). Examining the Influence of Transformational Leadership, Organizational Commitment, Job Embeddedness, and Job Search Behaviors on Turnover Intentions in Intercollegiate Athletics. Leadership and Organization Development Journal, 35(8), 755-740.

Permatasari, D. V., \& Saladin, G. I. (2017). Pengaruh Kepemimpinan Transformasional Terhadap Organizational Citizenship Behavior (OCB) dan Komitmen Organisasional Melalui Mediasi Kepuasan Kerja Karyawan PT. Bank Panin, Tbk Banjarbaru. Jurnal Bisnis Dan Pembangunan, 6(1), 36-42.

Putra, I. P. D. S. S. (2016). Pengaruh Perceived Organizational Support dan Komitmen Organisasional Terhadap Turnover Intention Karyawan. E-Jurnal Manajemen Unud, 5(10), 6260-6287.

Rahmawati, M., \& Wahyuningsih, S. (2018). Pengaruh Komitmen Organisasi, Stress Kerja dan Career Growth terhadap Intensi Turnover Karyawan (Studi Kasus Pada PT. Kini Jaya Indah). Fokus Ekonomi, 13(1), 102-121.

Rarasanti, P. I. A., \& Suana, I. W. (2016). Pengaruh Job Embeddedness Kepuasan Kerja dan Komitmen Organisasional Terhadap Turnover Intention Karyawan. E-Jurnal Manajemen Universitas Udayana, 5(7), 1-20.

Rohmawati, I. (2017). Pengaruh Gaya Kepemimpinan Transformasional dan Kompensasi Terhadap Intensitas Turnover yang Dimediasi Kepuasan Kerja Pada Karyawan Bagian Sewing PT Maxmoda Indo Global. Journal of Management UNPAND, 3(3), 1-10.

Sartika, D. (2014). Pengaruh Kepuasan Kerja dan Gaya Kepemimpinan Transformasional Terhadap Keinginan Keluar Karyawan dengan Komitmen Organisasi Sebagai Variabel Mediasi (Studi Kasus Di Cv. Putra Tama Jaya). Management Analysis Journal., 3(2), 1-20.

Satwari, T., Musadieq, M., \& Afrianty, T. W. (2016). Pengaruh Komitmen Organisasional terhadap Turnover Intention (Survei pada Karyawan Hotel Swiss-Belinn Malang). Jurnal Administrasi Bisnis, 40(2), 177-186.

Sianipar, A. R. B., \& Kristiana, H. (2014). Hubungan Komitmen Organisasi dan Kepuasan Kerja dengan Intensi Turnover pada Karyawan Bidang Produksi CV. X. Psikodimensia, 13(1), 98-114.

Sitorus, M. . A. M., \& Kasmiruddin. (2017). Pengaruh Kepemimpinan Transformasional dan Komitmen Organisasional Terhadap Turnover Intention (Studi Pada Hotel Ratu Mayang Garden Pekanbaru). Jurnal Online Mahasiswa Fakultas Ilmu Sosial Ilmu Politik, 4(2), 1-10. 
Suardani, N. M. . (2018). Pengaruh Pemberdayaan, Kepemimpinan Transformasional dan Keadilan Organisasional terhadap Komitmen Organisasional Karyawan. E-Jurnal Manajemen Unud, 7(3), 1426-1451.

Syarief, A., Maarif, M. S., \& Sukmawati, A. (2017). Pengaruh Gaya Kepemimpinan dan Budaya Organisasi Terhadap Komitmen Organisasi dan Perilaku Kewargaan Organisasi. Jurnal Manajemen Dan Organisasi, 8(3), 173-188.

Thakre, N. (2015). Organizational Commitment and Turnover Intention in BPOITeS and Retail Sector Employees. Journal of Psychosocial Research, 10(1), 89-98.

Yadav, V., \& Misra, N. (2015). The Effect of Transformational Leadership and Organizational Commitment on Turnover Intention of Semi-Skilled Workers in Small Scale Industries. International Journal of Research in Business Studies And Management, 2(8), 8-16.

Yukl, G. (2015). Kepemimpinan dalam Organisasi (5th ed.). Jakarta: Gramedia Pustaka. 